\title{
REVOLUTION AND REVOLUTIONARY Movements in Latin America: A Special Teaching and Research Collection of The Americas
}

\begin{abstract}
7 his curated collection of The Americas explores revolution and revolutionary movements in Latin American history from the colonial L period to the present. This theme embraces events and processes contributing to the courses, outcomes, and reactions to both moments conventionally labeled "revolutions" in Latin American history, such as largescale events like the Mexican Revolution, and more disparate efforts to secureor resist-sociopolitical change.
\end{abstract}

The choice of this theme is designed to spotlight the ways in which articles appearing in The Americas have engaged with, and intervened in, the historiography on revolution in Latin America. The compilation takes a broad geographic and temporal approach, and includes scholarship devoted to a variety of Latin American countries in the late-colonial and national periods. This collection highlights how conceptual and analytical trends-the cultural turn, for instance - and methodologies - material or visual culture studies, for example-have contributed to historians' different approaches to the study of revolution over the years, influencing the questions asked and the conclusions drawn. In addition to citing journal articles published from the late 1940s to the 2010s, we include references to monographs and articles published elsewhere, to give readers a sense of other historical scholarship produced contemporaneously with a given article.

In this introduction, I draw out three main themes-resistance, reaction, and solidarity - that flow out of a reading of the articles included in this collection and may be useful frameworks for orienting readers' engagement with the curated compilation's contents.

My thanks to Ben Vinson III, Eric Zolov, and the other members of the editorial board at The Americas for their insightful comments and helpful guidance in preparation of this introduction and curated collection. 
In his classic study of the Haitian Revolution, C. L. R. James outlined the multiplicity of factors to which historians might direct their critical attention when unraveling the intricacies of revolutionary movements. To excavate the "subsoil" from which revolution emanated at "moments when society is at a boiling point and therefore fluid," James advised scholars to attend to a plethora of interacting forces: economics, society and politics, and the actions of both individuals and "the masses." Mapping these causal factors and their connections would render the apparently "meaningless chaos" of revolutions legible. ${ }^{1}$

This curated collection of The Americas works in the tradition of James's approach, spotlighting scholarship published since the journal's inception in 1944 that has explored, from a variety of methodological and analytical approaches, the constellation of forces that have propelled moments at which Latin American societies have been exceptionally fluid. This compilation embraces an expansive definition of the term "revolution," attending to study of diffuse instances of popular mobilization and events conventionally labelled "revolutions" by placing scholarship dedicated to movements that sought to alter fundamental characteristics of Latin American societies in the colonial and national periods into dialogue. The collection thus illuminates the roots of resistance, reaction, and solidarity that animated the origins, processes, and outcomes of revolutionary currents. Simultaneously, the collection demonstrates The Americas' critical interventions into the historiography of revolution. The selected articles, ordered by date of publication, provide a snapshot of how pivotal historiographic shifts - the rise of women's history, the cultural turn-and transformative moments - the Cuban Revolution of 1959 or the proliferation of reactionary military dictatorships in the 1970s and 1980s - in Latin American history shaped historians' questions and conclusions regarding revolution's nature, and conditioned the methodological strategies through which they attempted to access the histories of revolutionary moments.

The first trio of articles illustrates an early tendency to examine revolution through its leaders. Bernard Bobb's (1947) study of José Artigas's Independence-era exploits in the Banda Oriental, William H. Gray's (1950) analysis of José San Martín's social reforms, and Mary Aquinas Healy's (1953) discussion of Toussaint L'Ouverture's contributions to independence movements in the Americas reflect a slant toward "great-man histories." These biographic accounts foregrounded leaders' personalities, thought, and goals. Overlaid with the contemporary emphasis in the United States on opposing

1. C. L. R. James, The Black Jacobins: Toussaint L'Ouverture and the San Domingo Revolution (New York: Random House, 1963), xi. 
dictatorships in the post World War II and early Cold War periods, these studies veered close to adulation of Independence-era leaders as heroic champions of liberty. Bobb, for example, praised Artigas as "the most gaucho among all gauchos" and admired his "adherence to ideals and tenacity of purpose." 2 Healy's portrait of L'Ouverture as a pragmatic liberator and advocate of raceless nationhood countered former colonial powers' nationalist histories, many of which maligned L'Ouverture. Amid decolonization's rising tide and an embryonic civil rights movement in the United States, L'Ouverture's rehabilitation aimed at an "objective interpretation of Haitian history" and focused on a man who, Healy speculated, "would have been surprised if he had known that even in 1953 race barriers still exist, though fortunately they are gradually breaking down." 3

From the 1960s onward, scholarship published in The Americas made an increasingly concerted effort to attend to ordinary Latin Americans' experiences, such as those of campesinos, the economic forces they confronted, and the interactions between revolutionary states and various constituencies. This shift bore the imprints of structural materialism, refined Marxist historiography, and social history's ascendancy. Reassessments of the Mexican Revolution of 1910 dominated. ${ }^{4}$ This strand demonstrated ambivalence regarding the Revolution's progressive nature, a view conditioned by Mexico's growing authoritarianism after 1940, and, by decade's end, the repression meted out in the Tlatelolco massacre of 1968. Joe Ashby's (1963) piece traces the vision in Cárdenas-era labor theory of a "wedded and co-dependent" relationship between an influential state and labor, forged through a blend of orthodox socialism and solutions tailored to the Mexican context. ${ }^{5}$ John

2. Bernard Bobb, "José Artigas," The Americas 4:2 (October 1947): 200.

3. Mary Aquinas Healy, "The Contributions of Toussaint L'Ouverture to the Independence of the American Republics, 1776-1826," The Americas 9:4 (April 1953): 426.

4. The literature on the Mexican Revolution is voluminous. The historiographic debate, particularly since the 1960s, has turned on the question of the Revolution's nature-progressive or conservative-and the relationship between the Revolution's goals and twentieth-century Mexico's authoritarian politics. Frank Tannenbaum's work, including The Mexican Agrarian Revolution (New York: The MacMillan Company, 1929), is often credited with establishing a view of the Revolution as popular and agrarian. Revisionist interpretations, like that of Ramón Eduardo Ruiz in The Great Rebellion: Mexico, 1905-1924 (New York: Norton: 1980), emphasize the Revolution's limited gains and characterize the conflict as one that birthed a state whose conservative bent was evident as early as the 1920s. Work produced since the 1980s explores the Revolution's cultural politics, the interactions between localities and the state, and regional variations. See for example Mary Kay Vaughan, Cultural Politics in Revolution: Teachers, Peasants and Schools in Mexico, 1930-1940 (Tucson: University of Arizona Press, 2013); and Ben Fallaw, Religion and State Formation in Postrevolutionary Mexico (Durham: Duke University Press, 2013). Alan Knight and Jaime Rodríguez's The Mexican Revolution, 1910-1940 (New York: Oxford University Press, 2011) provides a concise overview of the current state of the field. For a historiographic assessment published contemporaneously with Hart's articles, see David C. Bailey, "Revisionism and the Recent Historiography of the Mexican Revolution," Hispanic American Historical Review 58:1 (February 1978): 62-79.

5. Joe C. Ashby, "Labor and the Theory of the Mexican Revolution under Lázaro Cárdenas," The Americas 20:2 (October 1963): 172 . 
Hart's pair of articles $(1972,1974)$ analyze nineteenth-century agrarian and urban labor organizing as the preludes to the Revolution. Hart locates the Revolution's genesis in "land polarization," the conflict between campesinos and bacendados and the chronic economic and political instability that prompted the working class to organize "virtually in self-defense." While recognizing the limits of agrarian and labor mobilizations, Hart's attention to the development of those movements and their grievances deepened understanding of the Revolution's economic, social, and ideological roots.

Histories produced from the 1960s forward also shared an emphasis on US attempts to steer political change in Latin America. ${ }^{7}$ Inspired by New Left scholarship's animosity to US efforts to quell perceived Communist infiltration in the Western Hemisphere and further abroad, tactics modeled in the US-directed coup against Guatemala's democratically elected president in 1954, vociferous reaction against Fidel Castro's revolutionary government in Cuba, and escalating engagement in the Vietnam War, historians' concerns shifted toward enhanced, and often critical, attention to US foreign policy and its interventionist posture. George Baker's (1965) study of Woodrow Wilson's non-recognition policy in Costa Rica following Federico Tinoco's assumption of power in 1917, published three months after President Lyndon Johnson invaded the Dominican Republic, is emblematic of this reorientation. Baker charges that Wilson's default response to revolution, applied to Mexico, Nicaragua, and Costa Rica, represented "self-righteous meddling" that perpetuated economic and political instability "in a nation of strategic importance to the U.S." ${ }^{8}$ US intervention was similarly underscored in studies of the role of Latin American militaries in revolution. The authoritarian military dictatorships installed in the Southern Cone in the 1970s, such as that of Augusto Pinochet in Chile, and the escalating repression carried out in the Guatemalan Civil War, might account for historians' desire to approach revolution by explaining the entrenchment of Latin American militaries. Louis A. Pérez's (1974) article explores how US intervention, the Cuban military's self-preservation instinct, and the desire to avoid an "open

6. John Hart, "Agrarian Precursors of the Mexican Revolution: The Development of an Ideology," The Americas 29:2 (October 1972); John Hart, "Nineteenth Century Urban Labor Precursors of the Mexican Revolution: The Development of an Ideology," The Americas 30:3 (January 1974): 309.

7. William Appleman Williams's The Tragedy of American Diplomacy (Cleveland: World Publishing Co., 1959) is a primary root of the historiographic lineage that stressed the US's expansionist and imperialist tendencies. Attention to the influence of US foreign policy, and indictment of its goals and tactics, have remained touchstones of scholars' evaluation of Latin American revolutions. Two prominent examples are Walter LaFeber, Inevitable Revolutions: The United States in Central America (New York: Norton: 1983), and more recently Greg Grandin and Gilbert M. Joseph, eds., A Century of Revolution: Insurgent and Counterinsurgent Violence During Latin America's Long Cold War (Durham: Duke University Press, 2010).

8. George W. Baker, "Woodrow Wilson's Use of the Non-Recognition Policy in Costa Rica," The Americas 22:1 (July 1965): 21 . 
revolution" propelled Gerardo Machado's downfall in 1933. The result was an institutional alignment that established the "praetorian tradition" to which Castro's revolution responded. ${ }^{9}$ Kenneth Grieb's (1976) piece highlights the alliance between professionalized junior officers in the Guatemalan military and middle-class youth as the decisive factor in the October Revolution of 1944. Writing in 1976, Grieb stressed that the "price to pay" for the military's prominent role, and the Constitution that rendered the army "virtually independent," was a structure wherein the middle class remained beholden to the armed forces. ${ }^{10}$

Grieb's analysis begins with a pledge to add nuance to the "stereotype of revolution." In the 1980s, social and cultural historians extended this approach by attending to the participation of marginalized sectors, particularly women and the indigenous. In the wake of the second-wave feminist movement, articles by Anna Macias (1980) and Barbara Miller (1984) in The Americas injected women's histories into the study of Latin American revolution. Macias's exploration of women intellectuals' critical role in articulating revolutionary philosophy, soldaderas, and the Revolution's female victims, opened up a historiographical trajectory that promised to enrich the field through attention to women's experiences and gender history. ${ }^{11}$ Her work, which integrates oral history, novels, and artwork, models the novel methodological approach of the cultural turn. Miller's analysis of Mexican Catholic women's activity in the Cristero rebellion extended this historiographic focus, while illuminating a significant paradox: although popular mobilization provided an arena for women's participation, gendered notions might surface to condition, and eventually restrict, women's political activity. ${ }^{12}$ A parallel historiographic strand highlighted the agency of indigenous groups and campesinos in sparking attempts at sociopolitical change. ${ }^{13}$ Peter Blanchard's (1982) study countered

9. Louis A. Pérez, Jr., "The Military and Political Aspects of the 1933 Cuban Revolution: The Fall of Machado," The Americas 31:2 (October 1974): 184.

10. Kenneth J. Grieb, “The Guatemalan Military and the Revolution of 1944," The Americas 32:4 (April 1976): 543 .

11. At the time of her 1980 article in The Americas on women in the Mexican revolution, Macias could point to only one monograph that investigated Mexican women's role in the Revolution. For a contemporary publication that also addressed this topic, see Shirlene Ann Soto, The Mexican Woman: A Study of Her Participation in the Revolution, 1910-1940 (Palo Alto: R \& E Research Associates, 1979).

12. Since 1980, historians have produced a vibrant literature on the roles of women and gender politics in mobilization. For recent examples, see contributions to Elizabeth Dore and Maxine Molyneux, eds., Hidden Histories of Gender and the State in Latin America (Durham: Duke University Press, 2000); Mary Kay Vaughan, Gabriela Cano, and Jocelyn Olcott, eds., Sex in Revolution: Gender, Politics, and Power in Modern Mexico (Durham: Duke University Press, 2007); and Jocelyn Olcott, Revolutionary Women in Postrevolutionary Mexico (Durham: Duke University Press, 2006). For an analysis contemporary with Macias's that probed the paradoxes of women's participation in the nascent Argentine right, see Sandra F. McGee, "The Visible and Invisible Liga Patriótica Argentina, 1919-26," Hispanic American Historical Review 64:2 (May 1984): 233-258.

13. Steve Stern's edited collection, Resistance, Rebellion, and Consciousness in the Andean Peasant World: 18th to 20th Centuries (Madison: University of Wisconsin Press, 1987), contains several excellent essays that encourage 
the image of indigenous "passivity" by tracing indigenous challenges to exploitation in Peru after the War of the Pacific. Eric Ching's (1998) reassessment of the 1932 peasant rebellion in El Salvador blends the history of labor, locality, ethnicity, and culture to foreground Salvadoran indigenous peasants' agency in propelling the revolt independently of the Communist Party (PCS). Significantly, this scholarship illuminated mobilization's particularities in discrete spaces by taking a regional or local approach. Blanchard analyzed indigenous action in the Peruvian sierra, while Ching examined indigenous peasant organizing in Nahuizalco.

Ching's piece, read alongside Charles Harris and Louis Sadler's (1982) article on the Mexican Revolution's "underside," points to the transformative role that expanding source bases played in reformulating histories of revolution. Ching's analysis rests on previously unavailable documentary evidence from Russia and El Salvador, released after the Soviet Union's dissolution and the end of the Cold War and the Salvadoran Civil War. Absent these new archival sources, the PCS's unwillingness to consider ethnicity in its organizing, and indigenous peasants' long history of grassroots action, might have remained silenced. Harris and Sadler's piece drew on recently declassified documents from the US Federal Bureau of Investigation's archives to reposition the Orozco rebellion of 1912 as a borderlands phenomenon. These documents enabled the two authors to construct El Paso as a nexus of weapons smuggling and intelligence, stretching the Revolution's geographic reach while promoting collaboration between historians of revolution and borderlands scholars.

The final group of articles reflects the influence of the cultural turn. From the 1980s forward, historians reoriented their focus to investigate revolutionary cultures' construction, memory, and representation. Ben Fallaw's (1997) piece employs a regional study of the Yucatán to demonstrate how the Cárdenas regime attempted to transform the nineteenth-century caste war's legacy to suit the consolidating revolutionary state's aims. Through analysis of the symbolism and ceremony employed in the state-sponsored Crusade of the Mayab in 1937, Fallaw demonstrates how the regime's cultural appropriation sought to subsume indigenous identities under a uniform "Mayanism," reinforced through cultural artifacts, and ultimately clashed with indigenous

readers to consider peasant action as being, as Stern puts it, "problematic rather than predictable." Monographs that expanded focus on the complexities of radicalization from the bottom up and campesino and indigenous agency, often through local studies that incorporate oral histories, include Jeffrey Gould, To Lead as Equals: Rural Protest and Political Consciousness in Chinandenga, Nicaragua (Chapel Hill: University of North Carolina Press, 1990); and Cindy Forster, The Time of Freedom: Campesino Workers in Guatemala's October Revolution (Pittsburgh: University of Pittsburgh Press, 2001). 
peasants' self-identification. Rebecca Earle's (1997) article investigates how information circulated in Independence-era New Granada. In tracing the way oral culture-including rumor, propaganda, and deliberate disinformationmoved through Independence-era New Granada and its strategic deployment, Earle reconstructs the medium through which revolutionary discourse and information traveled and were reworked.

The penultimate section of articles demonstrates an extension of the cultural approach, spotlighting work illustrative of the field's cross-fertilization with film, material culture, and visual studies. Christine Ehrick's (2006) analysis of Uruguayan cinema between 1910 and 1920 highlights the use of film by elite actors, particularly upper class women, during a transformative period marked by President José Battle's reforms, the construction of the welfare state, women's changing sociopolitical roles, and cresting creole nationalism. In this environment, beneficent cinema-film produced by and for social assistance organizations-was deployed to negotiate and reaffirm class and gender hierarchies. Jesús Cruz (2004) investigates the symbiosis between alterations in middle-class Spaniards' consumer culture and the formation of liberal identities, proposing a link between material and political culture and framing the nineteenth-century revolutions as "processes of cultural construction." 14 James Krippner's (2007) profile of photographer Paul Strand's work in Mexico in the early 1930s explores Strand's role in formulating Mexico's “'revolutionary' transformation through images." 15 These articles delve into the cultural and material tools used to structure the immediate environment, society, and nation in moments of flux.

The final inclusions point to revolutionary historiography's recent attention to youth culture, deep analysis of the intellectual roots of mobilization, and transnational links. ${ }^{16}$ Through a close reading of the publication

\footnotetext{
14. Jesús Cruz, "Building Liberal Identities in Ninteenth-Century Madrid: The Role of Middle-Class Material Culture," The Americas 60:3 (January 2004): 392.

15. James Krippner, "Traces, Images, and Fictions: Paul Strand in Mexico, 1932-34," The Americas 63:3 (January 2007): 359 .

16. A recent addition to the literature on the Mexican student movement and its interaction with non-student actors is Jaime Pensado's Rebel Mexico: Student Unrest and Authoritarian Political Culture During the Long Sixties (Stanford: Stanford University Press, 2013). Studies on youth movements in the Southern Cone include Patrick Barr-Melej, "Siloísmo and the Self in Allende's Chile: Youth, 'Total Revolution,' and the Roots of the Humanist Movement," Hispanic American Historical Review 86:4 (November 2006): 747-784; and Valeria Monzano, The Age of Youth in Argentina: Culture, Politics, and Sexuality from Peron to Videla (Chapel Hill: University of North Carolina Press, 2014). Tanya Harmer's "The View from Havana: Chilean Exiles in Cuba and Early Resistance to Chile's Dictatorship, 1973-1977," Hispanic American Historical Review 96:1 (February 2016): 109-146, explores transnational organizing in opposition to Pinochet's dictatorship. Jessica Stites-Mor's edited collection, Human Rights and Transnational Solidarity in Cold War Latin America (Madison: University of Wisconsin Press, 2013), highlights how understudied social actors constructed and spread visions of citizenship and community to spur mobilization against various forms of exclusion and repression generated by the Cold War.
} 
Contorno, Sebastián Carassai (2010) deconstructs how the Peronist experience, generational differences with their predecessors, and disagreement with their contemporaries pushed young Argentine intellectuals to adopt the view that "making culture was making politics" and to develop a vision of social revolution wherein Peronism was the precursor to change. Joaquín Chávez's (2014) piece employs a similar focus on youth culture, blending insights from transnational, Cold War and Global Sixties scholarship. Chávez illustrates the influence of the originally conservative Catholic Unity Action (ACUS) on the Salvadoran New Left, and this movement's use of multiple intellectual, cultural, and political traditions in the 1960s to construct alliances with rural peasant communities. Members' ideological renovation was sparked by the Second Vatican Council, the guidance of two Belgian priests, Catholic social thought, the "just war" doctrine, and personal experiences with intensified state repression. ${ }^{17}$ Dalia Antonia Muller's (2011) article traces the pursuit of intraLatin American solidarity by affiliates of the Cuban Revolutionary Party (PRC) who worked to secure support for the Cuban independence movement in the late nineteenth century. Muller proposes that investigating the reaction to this network's campaigns, which attracted the support of students and artisans but failed to secure broad allegiance from Latin American governments, aids in understanding the ways in which US intervention on the island was received, and points to the legacies of prior revolutionary struggles in conditioning support for future efforts. These pieces demonstrate the intricacies of the local, national, and international forces propelling mobilization.

This collection's march through The Americas' contributions to, and interventions in, the historiography on Latin American revolutionary currents illuminates scholars' use of evolving conceptual and methodological paradigms. At the same time, the compilation focuses on core concerns foundational to any study of popular mobilization. The initiatives of leaders, the actions of popular sectors, the creative strategies of marginalized groups, the influence of institutions, and the interplay between these forces, emerge as key motors of revolution. This collection highlights the reactionary impulses, driven by both external forces and internal sociopolitical dynamics, that have attended movements aimed at reform. Finally, this scholarship reflects enduring engagement with the question of solidarity in revolution and its aftermath, and the mechanisms through which alliances were forged within Latin America

17. Joaquín M. Chávez, "Catholic Action, the Second Vatican Council, and the Emergence of the New Left in El Salvador (1950-1975),” The Americas 70:3 (January 2014): 474-75, 479, 483. This article is drawn from a special issue on Latin America in the Global 1960s that contains several articles indicative of recent trends in the historiography of revolution, including Valeria Manzano, “'Rock Nacional' and Revolutionary Politics: The Making of a Youth Culture of Contestation in Argentina, 1966-1979," and Aldo Marchesi, "Revolution Beyond the Sierra Maestra: The Tupamaros and the Development of a Repertoire of Dissent in the Southern Cone." 
to generate, condition, and resist change. In the diverse methodological and conceptual approaches taken by the authors, this special curated collection illustrates how multi-pronged and versatile frameworks have enriched study of revolutionary movements. It is through these varied and analytically rigorous approaches that, to return to James's insight, the depth and breadth of the revolutionary "subsoils" and courses of "fluid" historical moments in Latin America's history can be unearthed.

\title{
University of Toronto \\ Toronto, Ontario
}

\author{
Erica Toffoli, PhD Candidate
}

\section{The Americas: Articles Referenced}

Ashby, Joe C. "Labor and the Theory of the Mexican Revolution under Lázaro Cárdenas." 20:2 (October 1963): 158-199. https://doi.org/10.2307/979139.

Baker, George W. "Woodrow Wilson's Use of the Non-Recognition Policy in Costa Rica." 22:1 (July 1965): 3-21. https://doi.org/10.2307/979421.

Blanchard, Peter. "Indian Unrest in the Peruvian Sierra in the Late Nineteenth Century." 38:4 (April 1982): 449-462. https://doi.org/10.1017/S0003161500048677.

Bobb, Bernard F. “José Artigas.” 4:2 (October 1947): 195-222. https://doi.org/10.2307/977969.

Carassai, Sebastián. "The Formation of a Post-Peronist Generation: Intellectuals and Politics in Argentina through the Lens of Contorno (1953-1959)." 67:2 (October 2010): 219-251. https://doi.org/10.1017/S0003161500005459.

Chávez, Joaquín M. “Catholic Action, the Second Vatican Council, and the Emergence of the New Left in El Salvador (1950-1975)." 70:3 (January 2014): 459-487. https://doi.org/10.1017/S0003161500003990.

Ching, Eric. "In Search of the Party: The Communist Party, the Comintern, and the Peasant Rebellion of 1932 in El Salvador." 55:2 (October 1998): 204-239. https://doi.org/10.2307/1008053

Cruz, Jesus. "Building Liberal Identities in 19th Century Madrid: The Role of Middle Class Material Culture." 60:3 (January 2004): 391-410. https://doi.org/10.1353/tam.2004.0007.

Earle, Rebecca. "Information and Disinformation in Late Colonial New Granada." 54:2 (October 1997): 167-184. https://doi.org/10.2307/1007740.

Ehrick, Christine. "Beneficent Cinema: State Formation, Elite Reproduction, and Silent Film in Uruguay, 1910s-1920s.” 63:2 (October 2006): 205-224. https://doi.org/10.1017/S0003161500062970.

Fallaw, Ben W. “Cárdenas and the Caste War That Wasn't: State Power and Indigenismo in PostRevolutionary Yucatán.” 53:4 (April 1997): 551-577. https://doi.org/10.2307/1008148.

Gray, William H. "The Social Reforms of San Martin." 7:1 (July 1950): 3-11. https://doi.org/10.2307/978513.

Grieb, Kenneth J. "The Guatemalan Military and the Revolution of 1944." 32:4 (April 1976): 524543. https://doi.org/10.1017/S0003161500071893.

Harris, Charles H., and Louis R. Sadler. "The 'Underside' of the Mexican Revolution: El Paso, 1912." 39:1 (July 1982): 69-83. https://doi.org/10.2307/981270.

Hart, John M. "Agrarian Precursors of the Mexican Revolution: The Development of an Ideology." 29:2 (October 1972): 131-150. https://doi.org/10.2307/979896.

"Nineteenth Century Urban Labor Precursors of the Mexican Revolution: The Development of an Ideology." 30:3 (January 1974): 297-318. https://doi.org/10.2307/980359.

Healy, Mary Aquinas. "The Contributions of Toussaint L'Ouverture to the Independence of the American Republics, 1776-1826.” 9:4 (April 1953): 413-451. https://doi.org/10.2307/978403. 


\section{Erica Toffoli}

Krippner, James. “Traces, Images, and Fictions: Paul Strand in Mexico, 1932-34.” 63:3 (January 2007): 359-383. https://doi.org/10.1017/S0003161500063793.

Macias, Anna. "Women and the Mexican Revolution, 1910-1920." 37:1 (July 1980): 53-82. https://doi.org/10.2307/981040.

Miller, Barbara. "The Role of Women in the Mexican Cristero Rebellion: Las Señoras y Las Religiosas." 40:3 (January 1984): 303-323. https://doi.org/10.2307/981116

Muller, Dalia Antonia. "Latin America and the Question of Cuban Independence." 68:2 (October 2011): 209-239. https://doi.org/10.1017/S0003161500006751.

Pérez, Louis A. "The Military and Political Aspects of the 1933 Cuban Revolution: The Fall of Machado." 31:2 (October 1974): 172-184. https://doi.org/10.2307/980637 